\title{
Slug inhibition increases radiosensitivity of oral squamous cell carcinoma cells by upregulating PUMA
}

\author{
FANGFANG JIANG, LIJIE ZHOU, CHANGBO WEI, WEI ZHAO and DONGSHENG YU
}

Department of Oral and Maxillofacial Surgery, Guanghua School of Stomatology, Hospital of Stomatology, Guangdong Provincial Key Laboratory of Stomatology, Sun Yat-sen University, Guangzhou, Guangdong 510055, P.R. China

Received March 16, 2016; Accepted May 23, 2016

DOI: $10.3892 /$ ijo.2016.3570

\begin{abstract}
As a new strategy, radio-gene therapy was widely used for the treatment of cancer patients in recent few years. Slug was involved in the radioresistance of various cancers and has been found to have an anti-apoptotic effect. This study aims to investigate whether the modulation of Slug expression by siRNA affects oral squamous cell carcinoma sensitivity to X-ray irradiation through upregulating PUMA. Two oral squamous cell carcinoma cell lines (HSC3 and HSC6) were transfected with small interfering RNA (siRNA) targeting Slug and subjected to radiotherapy in vitro. After transfection with Slug siRNA, both HSC3 and HSC6 cells showed relatively lower expression of Slug and higher expression of PUMA. The Slug siRNA transfected cells showed decreased survival and proliferation rates, an increased apoptosis rate and enhanced radiosensitivity to X-ray irradiation. Our results revealed that Slug siRNA transfection in combination with radiation increased the expression of PUMA, which contributed to radiosensitivity of oral squamous cell carcinoma cells. Thus, controlling the expression of Slug might contribute to enhance sensitivity of HSC3 and HSC6 cells toward X-ray irradiation in vitro by upregulating PUMA.
\end{abstract}

\section{Introduction}

Radio-gene therapy, which combined traditional radiotherapy with gene therapy, was developed rapidly in recent few years as a new strategy (1-3). It has the advantage of reducing X-ray irradiation dose while enhancing the efficacy of gene therapy. As the standard adjuvant treatment, radiotherapy has played an important role in controlling tumor growth, however, it may

Correspondence to: Professor Wei Zhao and Professor Dongsheng Yu, Guanghua School of Stomatology, Guangdong Provincial Key Laboratory of Stomatology, Sun Yat-sen University, Guangzhou, Guangdong 510055, P.R. China

E-mail: zhaowei3@mail.sysu.edu.cn

E-mail:yudsh@mail.sysu.edu.cn

Key words: Slug, radiosensitivity, oral squamous cell carcinoma, P53 upregulated modulator of apoptosis, apoptosis be sometimes ineffective and resulting in unnecessarily severe side effects due to a significant proportion of radiation resistance (4-7). As for gene therapy, one of the most pivotal reasons that restricts the clinical applications of it in treating tumors is poor target activity. Therefore, for successful prediction of radiotherapy resistance, it is crucial to find a radiosensitive tumor target and to understand the mechanisms underlying the development of radioresistance in tumors.

Slug (Snail 2), which belongs to the Snail family, is a highly evolutionarily conserved zinc-finger transcription factor. It presents an anti-apoptotic effect by regulation of the transactivation of PUMA, Bcl-2 and Bax expression $(8,9)$. The members of the Slug/Snail superfamily share a similar zinc finger domain and the same Snag domain (10). Slugdeficient cells were radiosensitive to DNA damage and the function of Slug in response to DNA damage seemed to be important for its function in both normal development and cancer $(11,12)$.

P53 upregulated modulator of apoptosis (PUMA), which has a powerful pro-apoptotic effect, is a key protein in apoptosis and might be a potential new target for radio-gene therapy (13-15). It has been reported that PUMA could increase sensitivity to radiation-induced apoptosis in certain kinds of tumor cells both in vivo and in vitro (15-19). As a suppressor of PUMA transcription, Slug plays an important role in the tumorigenesis and development of resistance to radiation therapy by suppressing the expression of PUMA $(15,20,21)$. Zhang et al found that in cholangiocarcinomas Slug might be a potential target as an inducer of PUMA and Slug inhibition could upregulate radiation-induced PUMA activity leading to cell apoptosis (15).

Although the role of Slug in cancer progression has been well understood, Slug inhibition induced alteration in radiosensitivity of OSCC cells has not been analysed. Thus, the aim of this study was to explore whether Slug inhibition could increase radiosensitivity of oral squamous cell carcinoma HSC3 and HSC6 cells by upregulating PUMA. The results indicated that after the combined treatment of Slug siRNA transfection and X-ray irradiation, the expression of Slug was reduced and PUMA expression was upregulated, resulting in increased cell apoptosis. These findings offer new insight into the relationship of Slug and PUMA in OSCC cells and provide a new kind of radio-gene therapy of OSCC. 


\section{Materials and methods}

Patients and tissue acquisition. Surgically resected OSCC specimens were obtained from 57 OSCC patients between September 2008 and April 2013 in the Stomatology of Sun Yat-sen University with written informed consents as a prospective study. All cases were divided into phase I to IV according to the UICC (Union for International Cancer Control) standard in 2002 and the experimental procedures were approved by the Research Ethics Committee of Sun Yat-sen University. A summary of the characteristics in the 57 OSCC cases are presented in Table I. In addition, 15 cases of normal tissue were collected as control.

Immunohistochemical staining. Immunohistochemistry was used to detect the expression of Slug and PUMA in OSCC specimens. Ten percent formalin-fixed and paraffin-embedded samples were cut into $4-\mu \mathrm{m}$ thick sections. The sections were deparaffinized using xylene and rehydrated through an increased grades of ethanol. After antigen retrieval, primary rabbit polyclonal antibodies to Slug and PUMA both at 1:200 dilution were added for treatment at $4^{\circ} \mathrm{C}$ overnight. Then immunohistochemical staining was performed according to the recommended protocol. Sections were considered either as positive or negative according to the presence or absence of brown staining in OSCC epithelial or stromal cells.

Cell culture. The human oral squamous cell carcinoma cell lines HSC 3 and HSC6 were obtained from the American Type Culture Collection and conserved in Guangdong Provincial Key Laboratory of Stomatology of Sun Yat-sen University. Cells were cultured in DMEM supplemented with fetal calf serum $(10 \%)$ in a humidified $5 \% \mathrm{CO}_{2}$ incubator at $37^{\circ} \mathrm{C}$. Cells were used in the exponential growth phase in all experiments.

Slug siRNA transfections. A validated negative universal control was used as a control for transfection. Three different strand Slug-targeting siRNA oligonucleotides were used together and the siRNA oligonucleotide that showed the highest knockdown efficiency of Slug mRNA in HSC3 and HSC6 cell lines was used for the experiments. The transfections were carried out using Lipofectamine ${ }^{\mathrm{TM}} \mathrm{RNAi}$ MAX according to the recommended protocol.

Radiation treatment and clonogenic survival assay. Irradiation was performed in a linear accelerator (RS2000, Hong Kong) at a dose rate of $1.31 \mathrm{~Gy} / \mathrm{min}$ at room temperature. HSC 3 and HSC6 cells were irradiated with five single-radiation doses $(0,2,4,6$ and 8 Gy) using X-ray-irradiation equipment and then returned to the incubator. Twenty-four hours after irradiation, cells were trypsinized and plated in $60-\mathrm{mm}$ dishes and incubated for 12-14 days to allow colony growth to assay their colony-forming ability. The colonies were stained with crystal violet and colonies containing $\geq 50$ cells were counted. Each experiment was repeated three times and the survival curves were plotted by GraphPad Prism 3.0 software program. For the treatment combination of Slug siRNA transfection and radiation, cells were first transfected with Slug siRNA, and then irradiated with $4 \mathrm{~Gy} \mathrm{X}$-ray according to previous description $24 \mathrm{~h}$ later. Both HSC3 and HSC6 cells were divided into five groups, including control group, scramble group, Slug siRNA group, radiation group and Slug siRNA combination with radiation group which were used for further analysis.

RNA isolation and real-time qRT-PCR. Total RNA was isolated from HSC3 and HSC6 cell lines in all treatment conditions using TRIzol reagent according to the manufacturer's instructions. Real-time qRT-PCR analysis was performed to validate mRNA expression with the one-step RT-PCR kit and glyceraldehyde-3-phosphate dehydrogenase (GAPDH) was used as an internal control. The nucleotide sequences of specific primers for mRNA amplification were designed using Beacon Designer Software and its sequences were as follows: the sequence of Slug: sense, CCTCCAAAAAGCCAAACTA CTA; antisense, GTGTGCTACACAGCAGCC; the sequence of PUMA: sense, CCAGGAAAGGCTGTTGTGCTG; antisense, TCACTC GGTTTGCACTGGTGA; the sequence of GAPDH: sense, TGATGGGTGTGAACCACGAG; antisense, TTGAAG TCGCAGGAGACAACC. The RT-PCR conditions were as follows: $95^{\circ} \mathrm{C}$ for $5 \mathrm{~min}$, followed by 40 cycles of $95^{\circ} \mathrm{C}$ for 15 sec, $60^{\circ} \mathrm{C}$ for $15 \mathrm{sec}$ and $72^{\circ} \mathrm{C}$ for $1 \mathrm{~min}$ and the final extension was $72^{\circ} \mathrm{C}$ for $5 \mathrm{~min}$. Relative gene expression levels were calculated using the $2^{-\Delta \Delta \mathrm{Ct}}$ method.

Western blot analysis. Western blot analysis was used to investigate the expression of Slug and PUMA protein according to the manufacturer's protocol. Cells in different groups were lysed in protein lysis buffer supplemented with $1 \mathrm{mM}$ of PMSF (phenylmethylsulfonyl fluoride) and protease inhibitor mixture. Protein concentration was measured by BCA protein assay kit and then diluted with $5 \mathrm{X}$ loading buffer and denatured for $10 \mathrm{~min}$ at $99^{\circ} \mathrm{C}$. Thirty grams of protein per lane in all treatment conditions were separated on $12 \%$ SDS-PAGE and subsequently transferred to a PVDF (polyvinylidene difluoride) membrane by electro-blotting. The membranes were blocked with $5 \%$ non-fat dry milk and incubated with the primary antibodies against Slug, PUMA, Caspase-3, Bax, $\mathrm{Bcl}-2$ and GAPDH (1:1,000 dilution) at $4^{\circ} \mathrm{C}$ for $6 \mathrm{~h}$. Then the membranes were washed with TBST and incubated with the secondary antibody for $1.5 \mathrm{~h}$ at room temperature. Membranes were detected according to an ECL (enhanced chemiluminescence) reagent kit instruction and visualized in the AlphaView SA system. Quantity One software was used for analysis.

Immunofluorescence. HSC3 and HSC6 cells were seeded in laser-scanning confocal Petri dishes and incubated at $37^{\circ} \mathrm{C}$ overnight. Firstly, after different treatments for $48 \mathrm{~h}$, cells were washed with PBS for three times and fixed in $4 \%$ paraformaldehyde for $20 \mathrm{~min}$ and then permeabilized with $1 \%$ Triton X-100 for $30 \mathrm{~min}$ and sequentially blocked in $1 \%$ BSA for $20 \mathrm{~min}$. Secondly, the treated cells were incubated with primary antibodies (Slug and PUMA) according to manufacturer's protocols for $18 \mathrm{~h}$ and then incubated with the corresponding secondary antibody for $1 \mathrm{~h}$. Lastly, DAPI (4',6-diamidino-2-phenylindole) was used to stain nuclei. Images were captured by confocal laser scanning microscopy.

Cell viability assay. HSC 3 and HSC6 cells were seeded into 96-well plates at 4,000 cells/well. After treatment as described above, $20 \mu$ l MTT (3-(4,5-dimethyl-2-thiazolyl)-2,5 -diphenyl- 
Table I. Relations of Slug and PUMA expression with clinicopathological profiles.

\begin{tabular}{|c|c|c|c|c|c|c|c|}
\hline \multirow[b]{2}{*}{$\begin{array}{l}\text { Clinicopathological } \\
\text { profiles }\end{array}$} & \multirow[b]{2}{*}{$\begin{array}{l}\text { No. of tumor } \\
\text { specimens (n) }\end{array}$} & \multicolumn{3}{|c|}{ Slug expression } & \multicolumn{3}{|c|}{ PUMA expression } \\
\hline & & $\mathrm{n}$ & $\chi^{2}$ & P-value & $\mathrm{n}$ & $\chi^{2}$ & P-value \\
\hline \multicolumn{8}{|l|}{ Age (years) } \\
\hline$>60$ & 36 & 25 & 0.047 & 0.828 & 9 & 0.267 & 0.605 \\
\hline$\leq 60$ & 21 & 14 & & & 4 & & \\
\hline \multicolumn{8}{|l|}{ Gender } \\
\hline Male & 25 & 16 & 0.403 & 0.526 & 5 & 0.199 & 0.655 \\
\hline Female & 32 & 23 & & & 8 & & \\
\hline \multicolumn{8}{|l|}{ Stage } \\
\hline $\mathrm{I}+\mathrm{II}$ & 22 & 11 & 5.627 & 0.018 & 9 & 6.669 & 0.010 \\
\hline III+IV & 35 & 28 & & & 4 & & \\
\hline \multicolumn{8}{|l|}{ Differentiation } \\
\hline Well & 15 & 11 & 5.956 & 0.051 & 4 & 0.201 & 0.904 \\
\hline Moderately & 29 & 16 & & & 6 & & \\
\hline Poorly & 13 & 12 & & & 3 & & \\
\hline \multicolumn{8}{|c|}{ Lymph node metastasis } \\
\hline Negative & 37 & 26 & 0.167 & 0.683 & 9 & 0.138 & 0.710 \\
\hline Positive & 20 & 13 & & & 4 & & \\
\hline Total & 57 & 39 & & & 13 & & \\
\hline
\end{tabular}

Table II. The expression of Slug and PUMA in OSCC tissues and normal tissues.

\begin{tabular}{|c|c|c|c|c|c|c|c|}
\hline \multirow[b]{2}{*}{ Group } & \multirow[b]{2}{*}{$\begin{array}{l}\text { No.of tumor } \\
\text { specimens (n) }\end{array}$} & \multicolumn{3}{|c|}{ Slug expression } & \multicolumn{3}{|c|}{ PUMA expression } \\
\hline & & $\mathrm{n}$ & $\chi^{2}$ & P-value & $\mathrm{n}$ & $\chi^{2}$ & P-value \\
\hline OSCC tissues & 57 & 39 & 8.607 & 0.003 & 13 & 10.508 & 0.001 \\
\hline Normal tissues & 15 & 4 & & & 10 & & \\
\hline
\end{tabular}

2-H-tetrazolium bromide, $5 \mu \mathrm{g} / \mu \mathrm{l}$ ) was added per well and incubated for $4 \mathrm{~h}$ at $37^{\circ} \mathrm{C}$ in a humidified environment at 24 , 48, 72, 96 and $120 \mathrm{~h}$ post-transfection. The supernatant was discarded and $200 \mu \mathrm{l}$ DMSO (dimethyl sulphoxide) was added to each well to dissolve the precipitate. Optical density (OD) value was measured at the wavelength of $570 \mathrm{~nm}$. Each test was repeated in eight wells and performed daily for five days.

Cell cycle assay. Cells in different groups were washed twice with PBS, harvested, fixed with $70 \%$ ethanol and then stained with propidium iodide (PI, $20 \mu \mathrm{g} / \mathrm{ml}$ ) for $30 \mathrm{~min}$ at $4^{\circ} \mathrm{C}$. Samples were analyzed by fluorescence-activated cell-sorting (FACS) flow cytometer and the data were elaborated using Modfit software. Each test was repeated in triplicate.

Annexin V staining. The Annexin V staining was performed to measure cell apoptosis according to the manufacturer's protocol. After treatment, HSC3 and HSC6 cells in the log phase of growth were collected and resuspended in binding buffer at a density of $10^{6}$ cells $/ \mathrm{ml}$. An Annexin V-FITC labeled Apoptosis Detection kit was used for the apoptosis assay and the percentage of apoptotic cells was quantified by flow cytometry. Each test was repeated in triplicate.

Statistical analysis. All data were performed using the SPSS17.0 software and the results are presented as mean \pm SD and determined by one-way analysis of variance (ANOVA) or $\mathrm{t}$-test of three replicate assays. $\mathrm{P}$-value $<0.05$ was considered to indicate statistical significance.

\section{Results}

The expression of Slug and PUMA in OSCC samples. First, the expression of Slug and PUMA were examined by the immunohistochemical staining respectively in human OSCC tissues and normal tissues (Fig. 1). As showed in Table II, Slug 
A

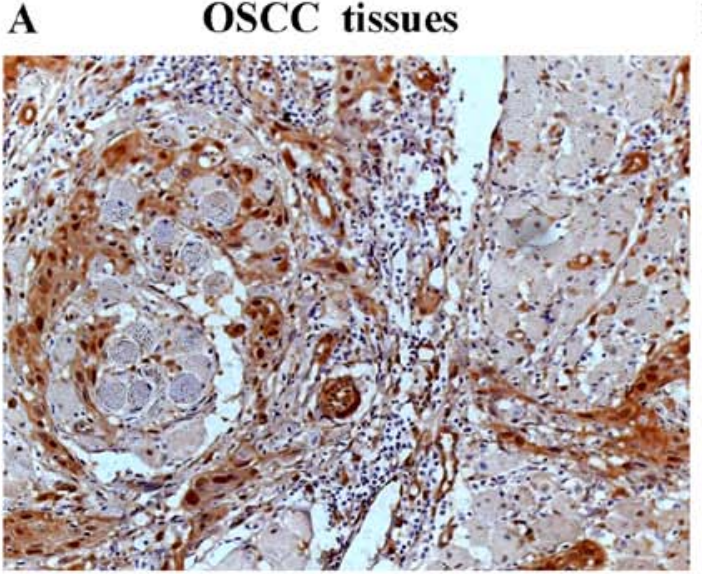

C

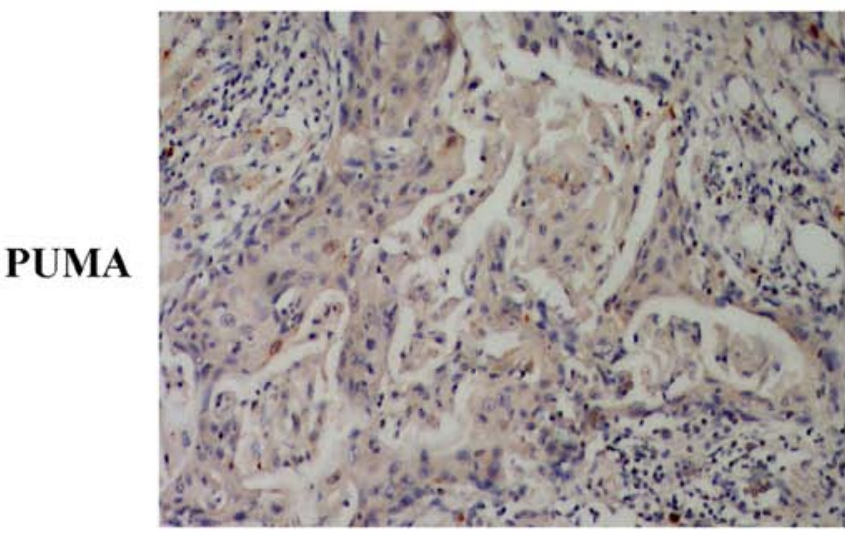

$\mathbf{E}$

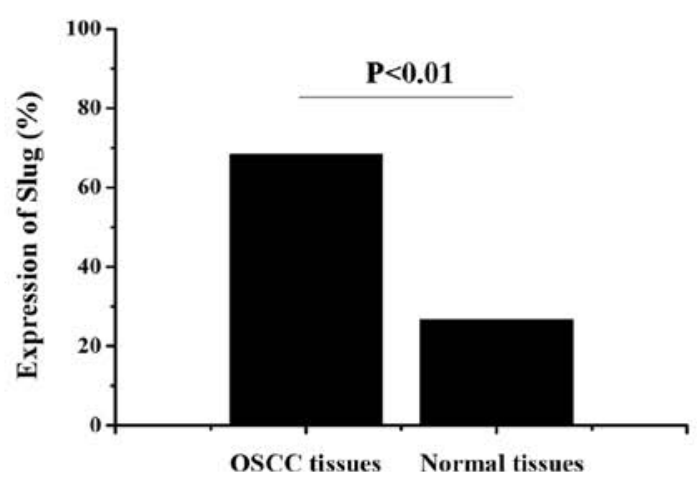

B

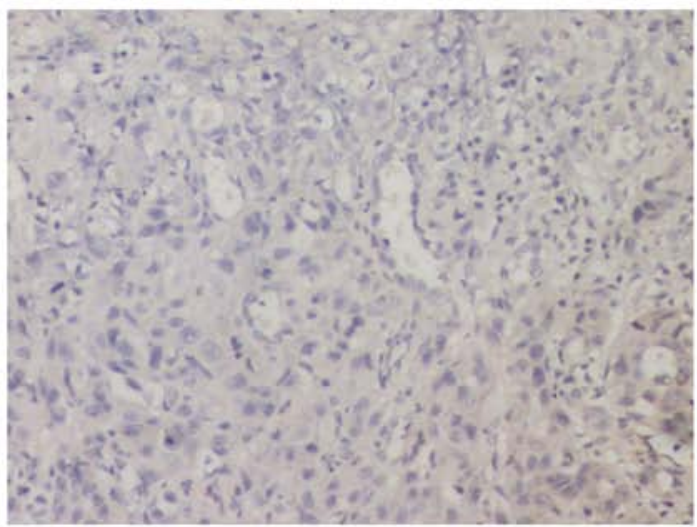

D

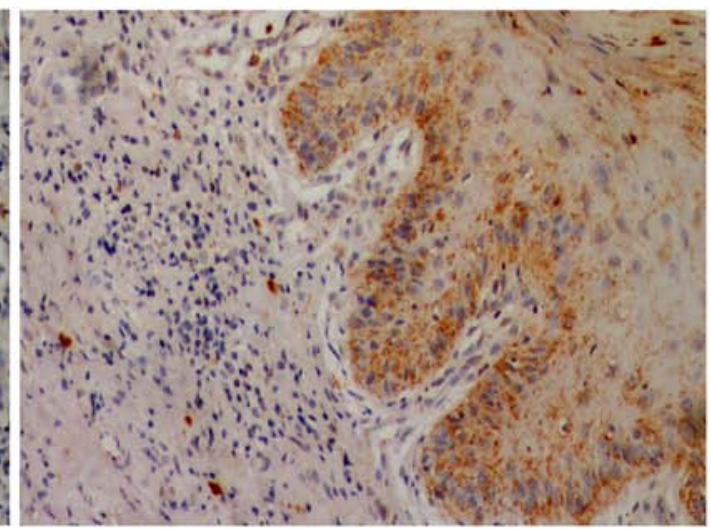

$\mathbf{F}$

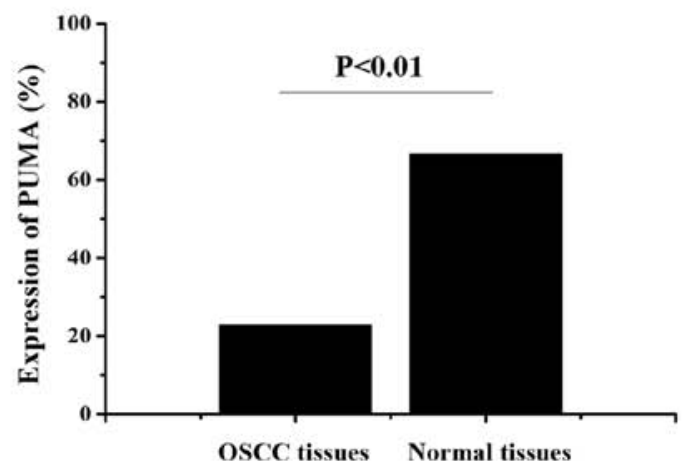

Figure 1. The expression of Slug and PUMA in OSCC samples. Immunohistochemical labeling of OSCC and normal tissues with anti-Slug antibody (A and B) and anti-PUMA antibody (C and D). (E and F) The positive rates of Slug and PUMA expression in OSCC and normal tissues. ${ }^{*}$ Statistical significance $(\mathrm{P}<0.05)$; and ${ }^{* *}$ obvious statistical significance $(\mathrm{P}<0.01)$.

expression was observed in $68.4 \%(39 / 57)$ of OSCC samples and in $26.7 \%(4 / 15)$ of normal tissues $\left(\chi^{2}=8.607, \mathrm{P}=0.003\right)$. In contrast, PUMA expression exhibited an opposite trend compared with the expression of Slug in OSCC samples $(22.8 \%, 13 / 57)$ and normal tissues $(66.7 \%, 10 / 15)\left(\chi^{2}=10.508\right.$, $\mathrm{P}=0.001)$. The results shoewed that the expression of PUMA was significantly higher than Slug in OSCC samples. The relationship between Slug and PUMA expression and clinicopathological profiles was evaluated (Table I). The expression of Slug was significantly lower in early stages (I+II) than in advanced stages (III+IV) $\left(\chi^{2}=5.627, \mathrm{P}=0.018\right)$. In contrast, PUMA expression was higher in early stages than in advanced stages $\left(\chi^{2}=6.669, P=0.010\right)$. The data showed that Slug and
PUMA expression was positively correlated with tumor stage $(\mathrm{P}<0.05)$ and negatively correlated with patient age, gender, tumor differentiation and lymph node metastases $(\mathrm{P}>0.05)$, suggesting that they play an important role in the progression of OSCC.

Slug siRNA transfection inhibits the expression of Slug at both $m R N A$ and protein levels in OSCC cell lines. We analyzed the effect of Slug siRNA on HSC3 and HSC6 cell lines (Fig. 2). RT-PCR and western blot analysis showed that Slug siRNA transfection resulted in a reduction at Slug mRNA (90-95\%) and protein (80-90\%) level in both cell lines compared with control or scramble group $\left({ }^{* *} \mathrm{P}<0.01\right)$. 

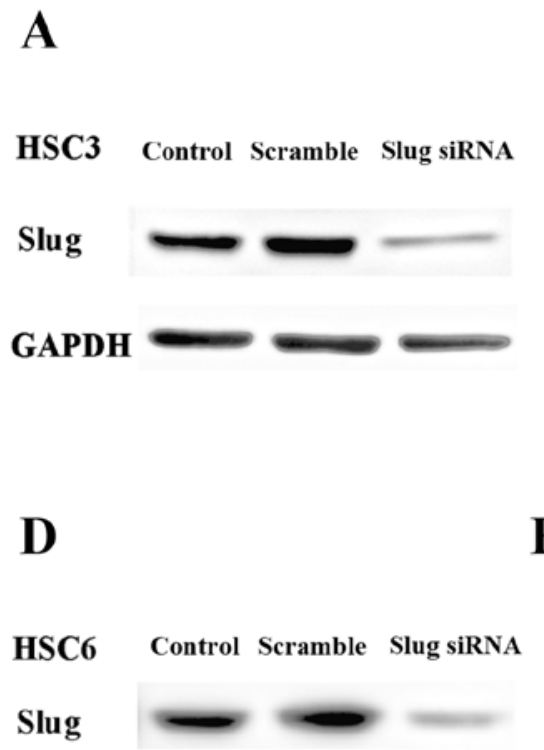

GAPDH
B

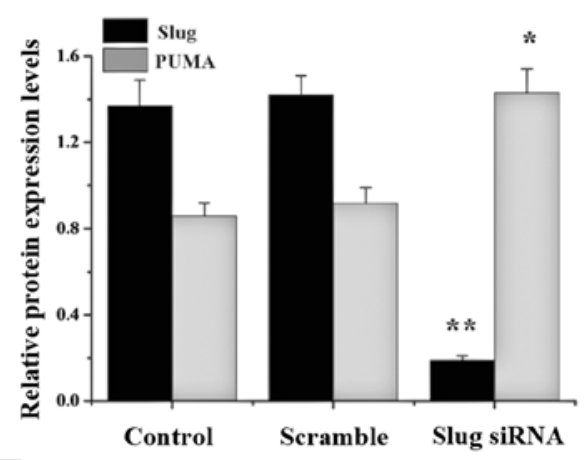

E

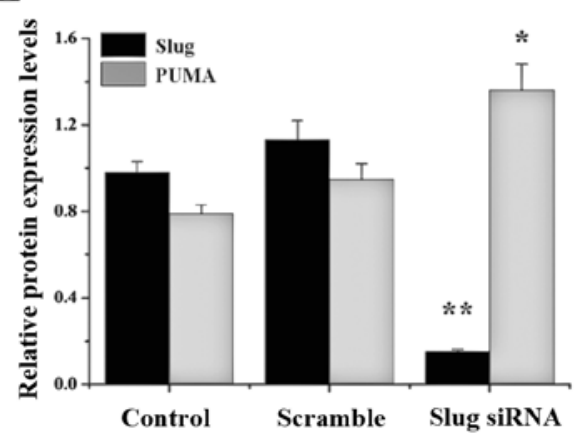

C
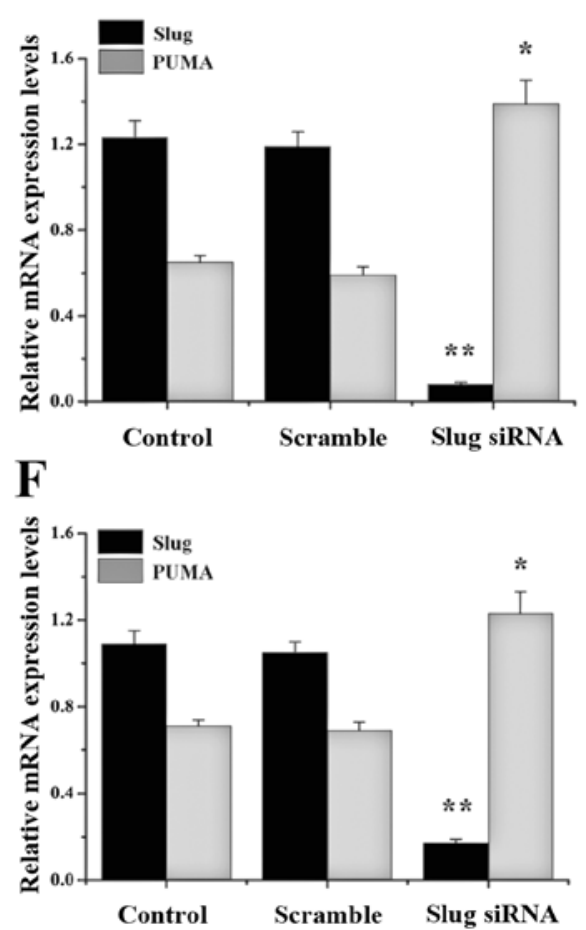

Figure 2. Expression of Slug protein and mRNA in HSC3 and HSC6 cells transfected with Slug siRNA. Both cell lines were found to express detectable levels of Slug protein and mRNA. (A and B) Western blot analysis for Slug protein in HSC3 cells. (C) RT-PCR analysis for Slug mRNA in HSC3 cells. (D and E) Western blot analysis for Slug protein in HSC6 cells. (F) RT-PCR analysis for Slug mRNA in HSC6 cells. Values indicated as mean \pm SD of three independent experiments. *Statistical significance $(\mathrm{P}<0.05)$; and ${ }^{* *}$ obvious statistical significance $(\mathrm{P}<0.01)$.

Knockdown of Slug upregulates PUMA expression in OSCC cell lines. PUMA is a common tumor suppressor gene and exhibited a very low expression in OSCC cell lines. In contrast, Slug was highly expressed in many tumors as an oncogene and has been shown to be involved in cell apoptosis by regulation of PUMA. Therefore, we intended to evaluate whether silencing of Slug plays an important role in upregulating PUMA in HSC3 and HSC6 cells. To assess the effect of endogenous Slug on PUMA expression, we transfected Slug siRNA into HSC 3 and HSC6 cells and analyzed the expression of PUMA mRNA by RT-PCR and analyzed PUMA protein expression by western blot and immunofluorescence analyses. The data showed that Slug expression was decreased and PUMA was upregulated in Slug siRNA group and no significant change of Slug and PUMA expression was detected in control or scramble group (Fig. 3).

Effect of Slug siRNA transfection on OSCC cell survival and radiosensitivity. To investigate the potential effects of Slug siRNA transfection alone or in combination with X-ray irradiation on HSC3 and HSC6 cell survival, clonogenic survival assay was applied. The results suggested that Slug inhibition could decrease cell proliferation and increase cell sensitivity to X-ray irradiation (Fig. 4). Statistical analysis showed that cell colony forming efficiency (Fig. 4B and E) and survival rate (Fig. 4C and F) were gradually decreased with the increasing radiation dose in control group $(\mathrm{P}<0.01)$, scramble group $(\mathrm{P}<0.01)$ and Slug siRNA group $(\mathrm{P}<0.01)$ of HSC 3 and HSC6 cells. Compared with the other two groups, cell colony forming efficiency and survival rate in Slug siRNA radiation group was significantly reduced at the same radiation dose $(\mathrm{P}<0.05)$ and there was no significant difference between control group and scramble group ( $\mathrm{P}>0.05)$. A dose of $4-\mathrm{Gy}$ was selected for subsequent experiments according to the survival rate $(50-70 \%)$ of OSCC cells.

Effect of Slug inhibition combined with X-ray irradiation on OSCC cell cycle and cell proliferation. We assessed whether Slug inhibition or/and X-ray irradiation treatment modulated cell cycle progress. Slug siRNA and X-ray irradition induced a significant increase in the percentage of $\mathrm{S}$ phase cells in HSC3 (Fig. 5A-C; P<0.05) and HSC6 (Fig. 5D-F; P<0.01) cells. To evaluate the synergistic effect of Slug siRNA and X-ray irradiation on cell proliferation, we used CCK8 assay to compare the growth of HSC3 and HSC6 cells when treated with Slug siRNA alone or with radiation. As shown in Fig. 5, HSC3 and HSC6 cells proliferated at a significantly lower rate in Slug siRNA/radiation group than did other groups at day 2 (HSC3 $\mathrm{F}=4.199, \mathrm{P}=0.019$; HSC6 $\mathrm{F}=3.623, \mathrm{P}=0.031$ ), day 3 (HSC3 $\mathrm{F}=4.121, \mathrm{P}=0.021 ; \mathrm{HSC6} \mathrm{F}=4.751, \mathrm{P}=0.013$ ) and day 4 (HSC3 $\mathrm{F}=3.464, \mathrm{P}=0.036$; HSC6 $\mathrm{F}=3.391, \mathrm{P}=0.039)$ and there was no obvious difference of cells proliferation at day 1 (HSC3 $\mathrm{F}=2.092, \mathrm{P}=0.137$; HSC6 $\mathrm{F}=0.586, \mathrm{P}=0.711$ ) and day 5 (HSC3 $\mathrm{F}=1.888, \mathrm{P}=0.170$; HSC6 $\mathrm{F}=1.944, \mathrm{P}=0.160)$. Thus, the results showed that Slug inhibition combined with X-ray irradiation could inhibit cell proliferation through increasing cells in $\mathrm{S}$ phase.

Radiation treatment affects the expression of proteins involved in apoptotic processes. To assess the effect of X-ray irradiation 
A

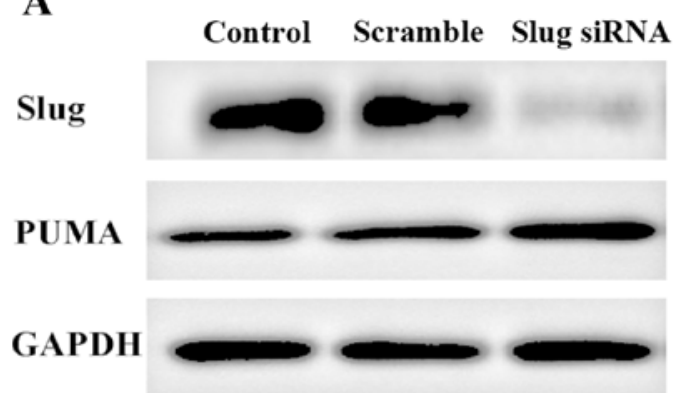

C

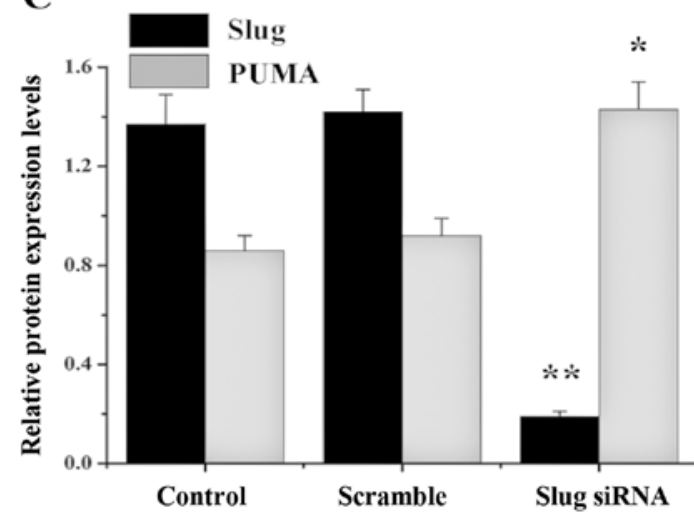

B

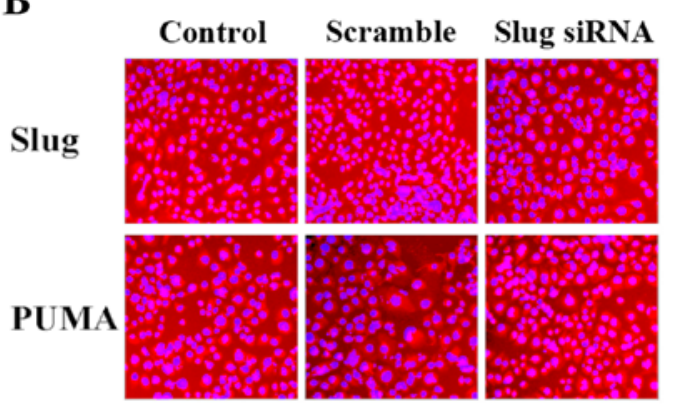

D

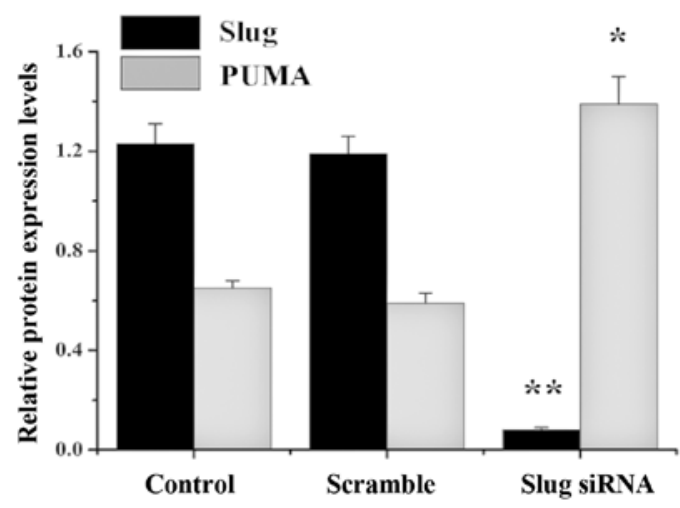

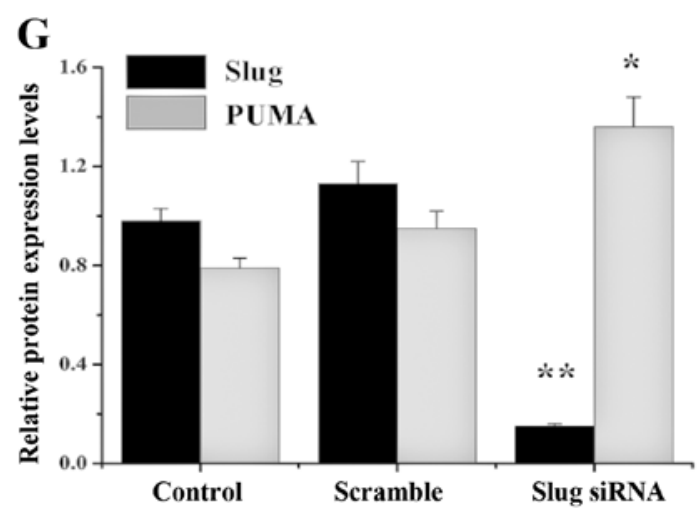
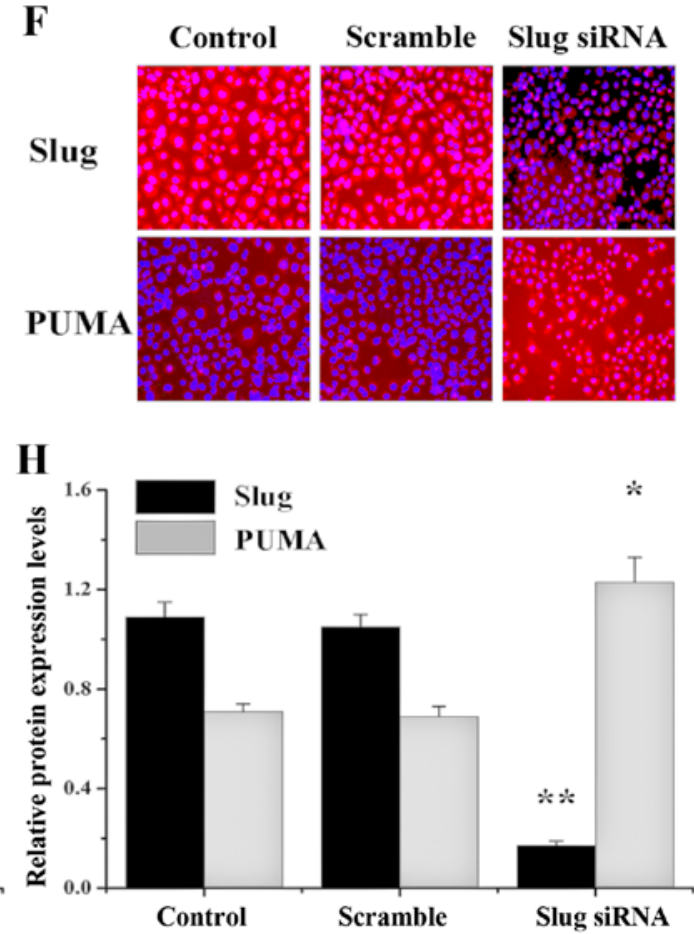

Figure 3. Expression of Slug and PUMA both at protein and mRNA levels in Slug siRNA transfected HSC3 (A-D) and HSC6 (E-H) cells. As determined by western blot analysis (A and E) and immunofluorescence (B and F), Slug was inhibited and PUMA exhibited an opposite trend in Slug siRNA group in HSC3 and HSC6 cells. (C and G) Relative expression of Slug and PUMA was quantified after normalization with the density of GAPDH by ImageJ Instrument software. (D and H) RT-PCR analysis was used to detect Slug and PUMA mRNA levels. Values indicated as mean \pm SD of three independent experiments. *Statistical significance $(\mathrm{P}<0.05)$; and ${ }^{* *}$ obvious statistical significance $(\mathrm{P}<0.01)$.

on the expression of Slug and PUMA, we analyzed Slug and PUMA expression at both mRNA and protein levels in HSC3 and HSC6 cells that received 4-Gy X-ray irradiation. Our data showed that the expression of Slug were strikingly higher in radiation group than control group, however, there was no obvious Slug upregulation in Slug siRNA group compared with radiation group. It was indicated that X-ray irradiation could improve Slug expression in HSC3 and HSC6 cells. 
A

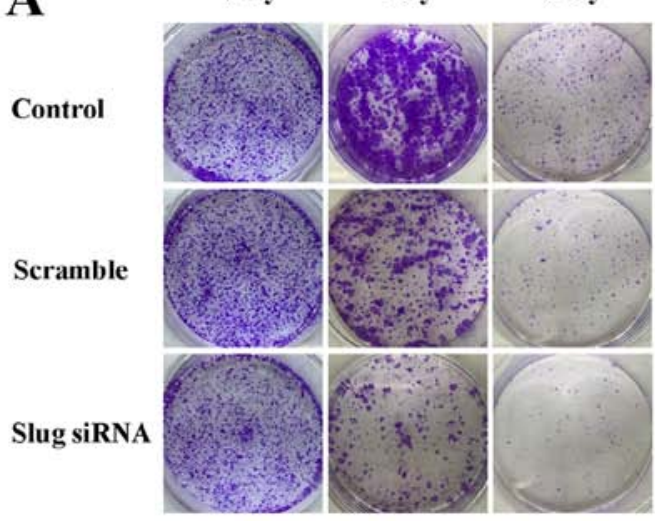

D

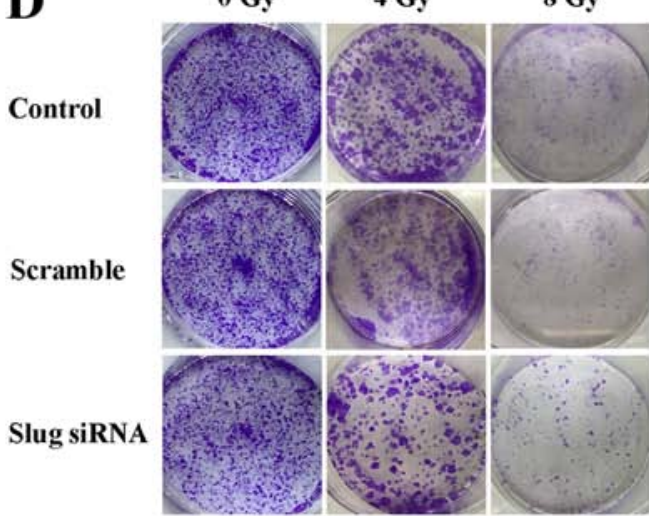

B

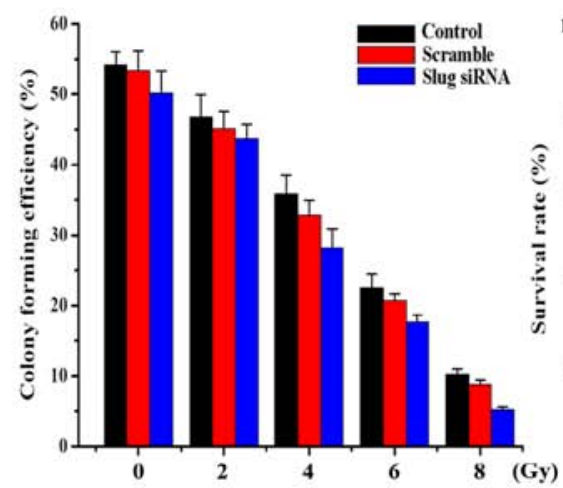

C

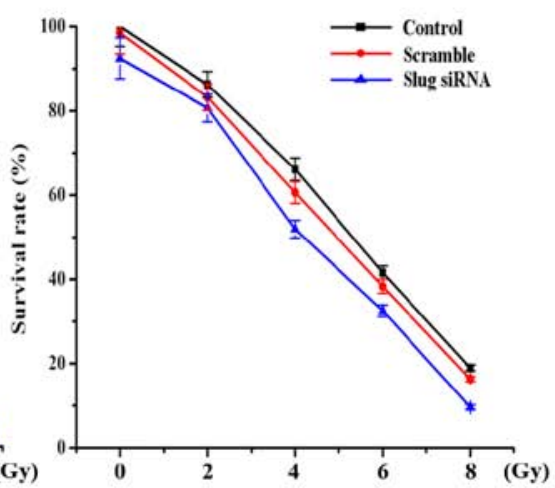

F

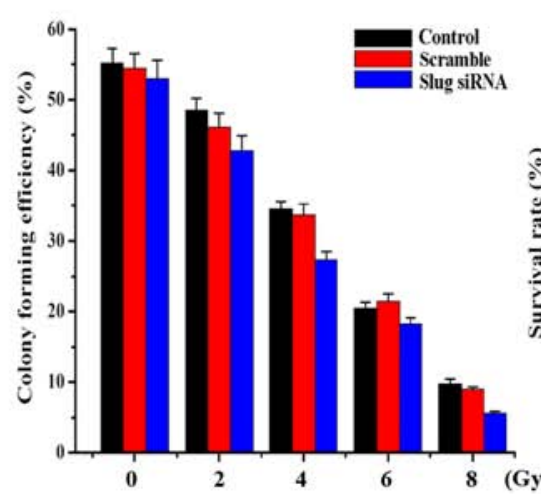

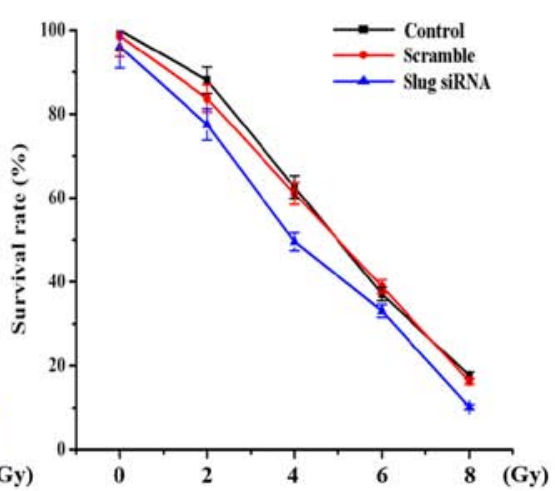

Figure 4. Effect of Slug inhibition and X-ray irradiation on cell survival. Clonogenic survival was assessed to detect cell survival of HSC3 (A-C) and HSC6 (D-F) cells treated with Slug siRNA 14 days after five single-radiation doses $(0,2,4,6$ and 8 Gy) exposure. Values are indicated as mean \pm SD of three independent experiments.

As for PUMA, the results showed that PUMA expression increased significantly after X-ray irradiation or Slug siRNA transfection compared with control group. To investigate the effect of Slug siRNA transfection in combination with X-ray irradiation on PUMA activity, we measured PUMA expression after the above treatment in HSC3 and HSC6 cells. RT-PCR and western blot analysis showed that cells treated with Slug siRNA transfection and radiation displayed notable increased PUMA expression when compared with radiation group or Slug siRNA group. The data indicated that both Slug siRNA transfection and radiotherapy could upregulate the expression of PUMA. In addition, Caspase-3 and Bax were observed to be overexpressed in Slug siRNA, radiation, scramble/radiation and Slug siRNA/radiation groups. In contrast, Bcl-2 exhibited an opposite trend (Fig. 6A and B).

Downregulation of Slug plus radiation induces OSCC cell apoptosis. RT-PCR and western blot analysis above displayed the upregulation of PUMA expression in Slug siRNA group, radiation group, scramble plus $\mathrm{X}$-ray irradiation group and Slug siRNA combination with radiation group. The impact of Slug siRNA transfection and X-ray irradiation on HSC3 and HSC6 cell apoptosis was evaluated by Annexin V assay. The apoptosis rate were statistically significant in each group both of HSC3 $(\mathrm{F}=24.344, \mathrm{P}<0.01)$ and HSC6 cells $(\mathrm{F}=32.843$, $\mathrm{P}<0.01)$. The data showed that the apoptotic cells were notably increased in cells treated with Slug siRNA and 4 Gy X-ray irra- diation (HSC3: 22.03 $\pm 1.23 \%$; HSC6: $24.06 \pm 1.67 \%$ ) compared with cells in Slug siRNA group (HSC3: $13.43 \pm 1.29 \%, \mathrm{P}=0.001$; HSC6: $15.25 \pm 1.01 \%, \mathrm{P}=0.006$ ), radition group (HSC3: $15.77 \pm 1.21 \%, \mathrm{P}=0.008$; HSC6: $16.36 \pm 1.28 \%, \mathrm{P}=0.016)$ and scramble plus X-ray irradiation group (HSC3: $15.11 \pm 1.67 \%$, $\mathrm{P}=0.004$; HSC6: $15.50 \pm 1.57 \%, \mathrm{P}=0.007)$, suggesting that cell apoptosis was obviously induced when treated with Slug siRNA and X-ray irradiation. There was no remarkable changes of cell apoptosis in control (HSC3: 4.08 $\pm 0.56 \%$, HSC6: $4.75 \pm 0.91 \%$ ) or scramble group (HSC3: $5.06 \pm 0.75 \%$, $\mathrm{P}=0.626$; HSC6: $5.53 \pm 0.85 \%, \mathrm{P}=1.000$ ) (Fig. 6C and D).

\section{Discussion}

Oral squamous cell carcinoma (OSCC) is the most commom type of oral cancer and accounts for $>90 \%$ of it. Despite advances in the common treatments such as surgery, chemotherapy, radiotherapy or a combination of them for OSCC patients, the overall survival rate has not been drastically improved over the past few years (22-25). Radiotherapy played an important role in the treatment of OSCC, however, its efficacy was still limited mainly due to some patients exhibit tolerance to radiotherapy. Therefore, reducing the radiation tolerance and increasing sensitivity to radiotherapy has become a breakthrough to improve the efficacy of OSCC patients.

Slug is involved in the chemoresistance and radioresistance of several types of cancers $(26,27)$. As an E-cadherin repressor 
A

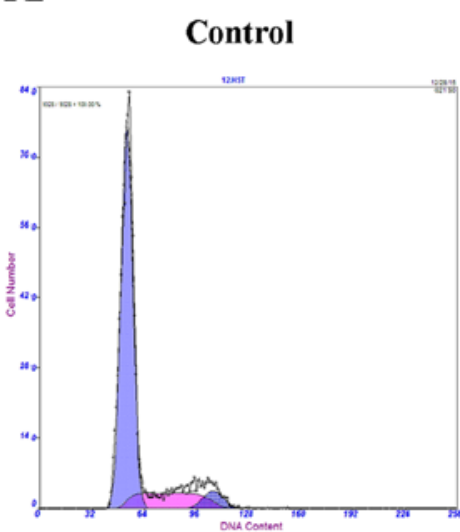

D

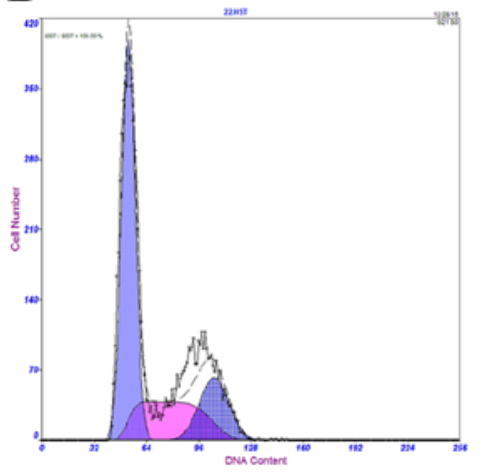

G

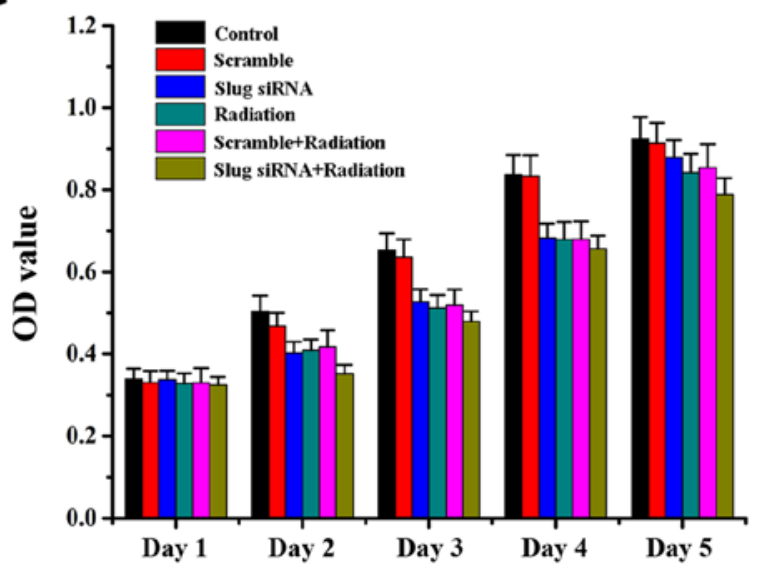

I

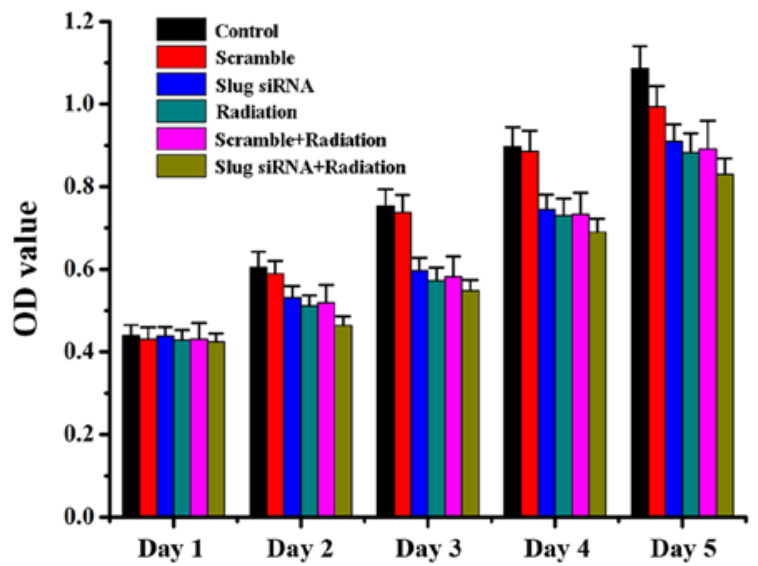

C

Slug $\operatorname{siRNA}+$ Radiation
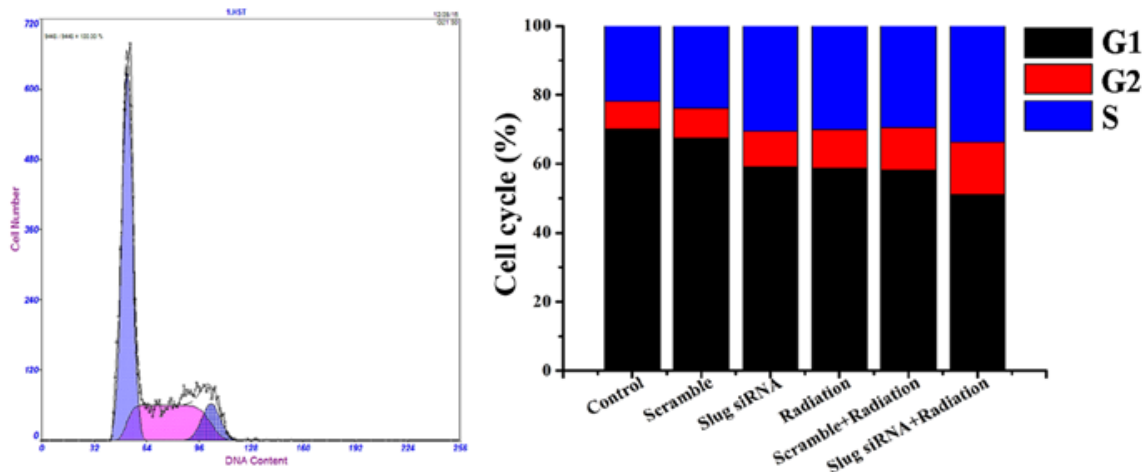

$\mathbf{E}$

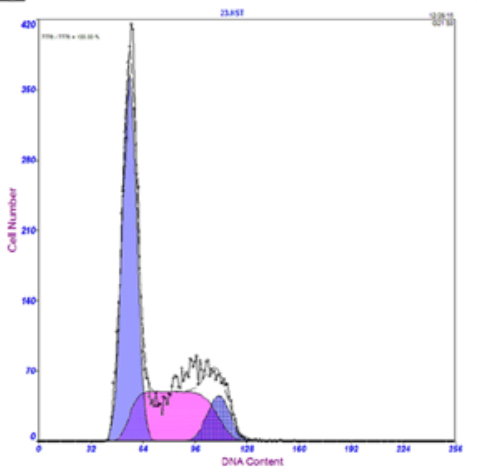

$\mathbf{F}$

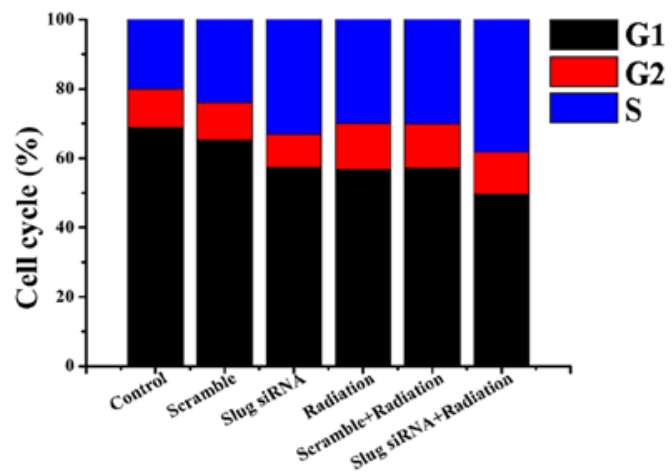

$\mathbf{H}$

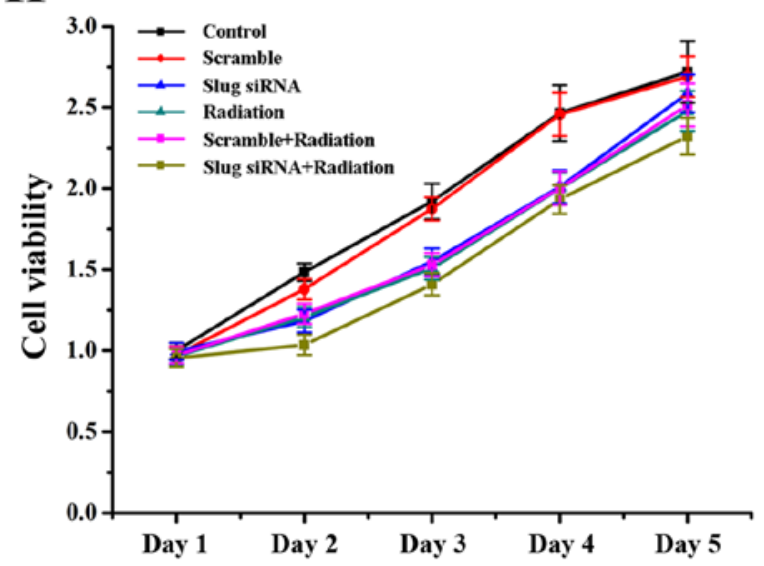

J

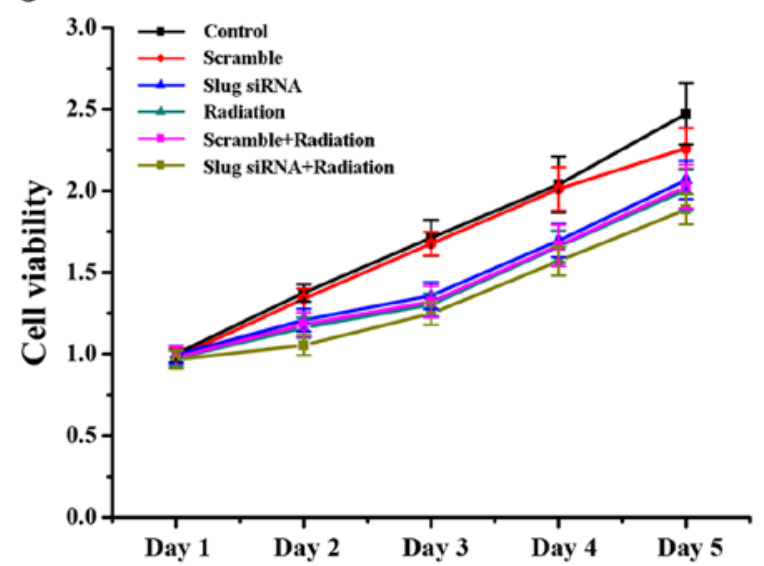

Figure 5. Slug siRNA and X-ray irradiation restrains OSCC cell proliferation. HSC3 (A-C) and HSC6 (D-F) cell cycles were detected by flow cytometry analyses in different groups. CCK8 assay was used to detect the growth of HSC3 (G and H) and HSC6 (I and J) cells treated with Slug siRNA and 4 Gy X-ray irradiation. Every experiment was done at least three times. 
A $\quad$ B

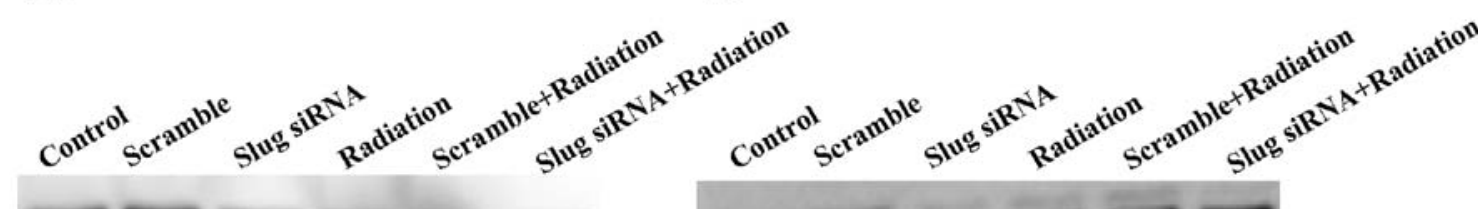

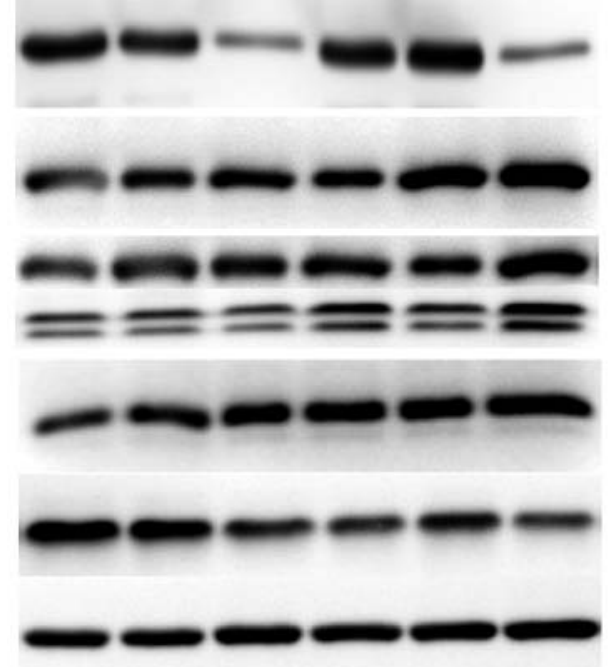

C

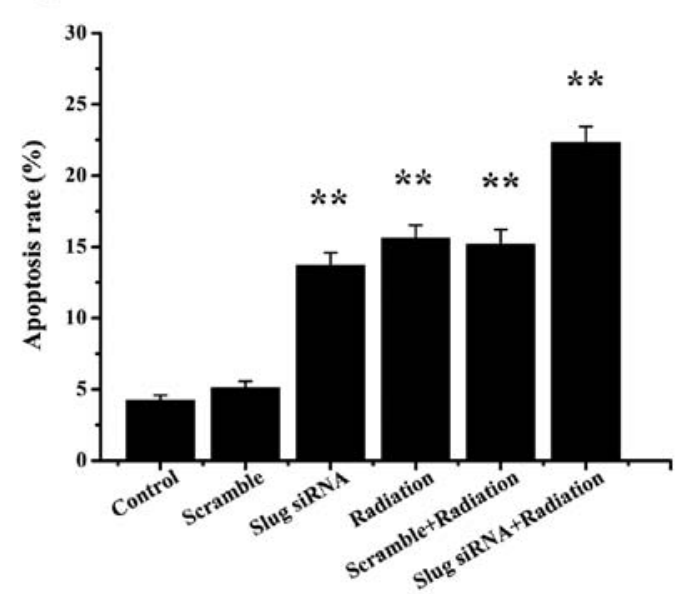

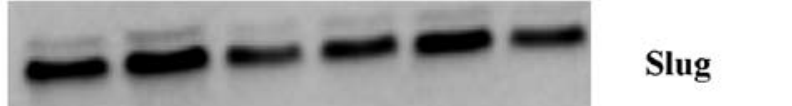

PUMA

Caspase-3

Bax

Bcl-2

GAPDH

D

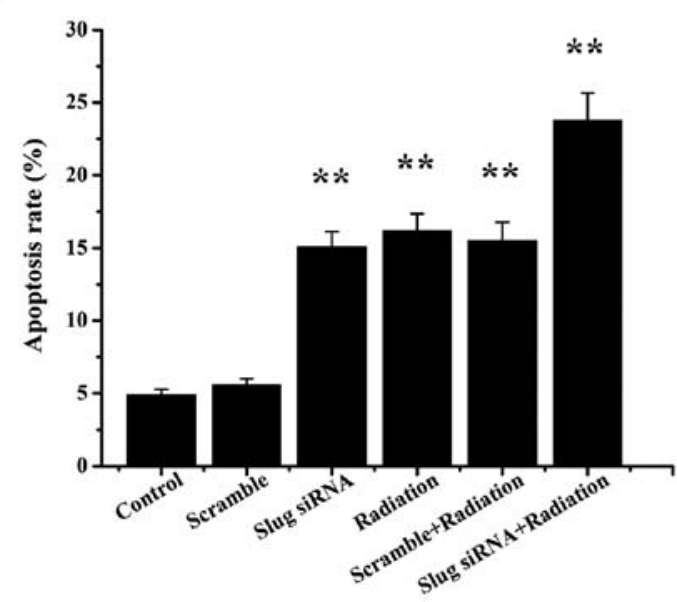

Figure 6. Downregulation of Slug plus X-ray irradiation induce apoptosis in OSCC cells. Western blot analysis of proteins involved in apoptotic processes was performed for HSC3 (A) and HSC6 (B) cell lines with the treatment of Slug siRNA transfection or/and X-ray irradiation. Percentages of apoptotic HSC3 (C) and HSC6 (D) cells are shown in the histogram. Values are indicated as mean \pm SD of three independent experiments. "Statistical significance (P<0.05); and **obvious statistical significance $(\mathrm{P}<0.01)$.

and a suppressor of PUMA, and Slug has been proved to play an important role in controlling cell apoptosis recently. Zhang et al (15) found that Slug is a considerable modulator of the therapeutic response of cholangiocarcinoma cells and may be potentially useful as a sensitizer in cholangiocarcinoma therapy. One of the mechanisms is the regulation of PUMA by Slug. Xu et al (8) found that Slug overexpression in CNE-2-RES cells may result in the radioresistance of cells and Slug mediates CNE-2 radioresistance via downregulation of PUMA in both a p53-dependent and p53-independent manner. Some studies (28) confirmed the survival function of Slug-PUMA axis in human breast cancer cells that Slug knockdown increased PUMA expression and inhibited lung colonization and demonstrated a pivotal role for Slug in carcinoma cell survival, which implied that disruption of the Slug-PUMA axis may impinge on the survival of metastatic cells. To assess the effect of endogenous Slug on PUMA expression in HSC3 and HSC6 cells, we transfected Slug siRNA into cells and analyzed the expression of PUMA mRNA and protein expression. In agreement with this notion, our data showed that Slug expression was decreased and PUMA was upregulated in Slug siRNA group which evaluated that silencing of Slug played an important role in upregulating PUMA expression in HSC3 and HSC6 cells.

As a member of the Bcl-2 family, PUMA was discovered in 2001 and identified as an essential mediator of p53-independent and p53-dependent apoptosis (29,30). PUMA was localized in the mitochondria and could kill a variety of human cancer cells by activating caspases through mitochondrial dysfunction (13,31). PUMA also functioned through other Bcl-2 family members, such as Bcl-2, Bcl-XL and Bax (32). Although the specific mechanism for PUMA inducing apoptosis needs 
further investigation, it has been shown to be a promising new terget in gene therapy $(33,34)$. The goal of this study was to explore the effect of combining Slug siRNA with X-ray irradiation on HSC3 and HSC6 cells. We found that downregulation of Slug expression was correlated with the sensitivity of OSCC cells to radiotherapy. However, further studies are needed to investigate the mechanism that Slug silencing exerts its antisurvival and pro-apoptotic effect in OSCC cells.

In this study, the inhibition of Slug was efficient in suppression of proliferation and induction of apoptosis in HSC3 and HSC6 cells. Surprisingly, the combination of Slug siRNA and X-ray irradiation induced a relatively higher apoptosis as compared with Slug siRNA or X-ray irradiation alone in OSCC cells. We performed the clonogenic survival assay which demonstrated that the treatment with Slug downregulation and $\mathrm{X}$-ray irradiation synergistically reduced clonogenia survival to address that the induction of apoptosis may lead to long-term response to radiotherapy. The data revealed that Slug downregulation potentially enhanced radiosensitivity of HSC3 and HSC6 cells in vitro by increasing PUMA expression.

In conclusion, this study indicates that Slug may be a potential target as an inducer of PUMA and inhibition of Slug by Slug siRNA may be a strategy to overcome radioresistance by upregulation of PUMA. These findings provided new information for novel combinational therapies using Slug siRNA to cooperate with X-ray irradiation in patients with OSCC.

\section{Acknowledgements}

This study was supported by the National Natural Sciences Foundation of China (nos. 81272554 and 81472526), the Guangdong Sciences and Technology Project (no. 2016A020216007).

\section{References}

1. Zhao Y, Li Z, Sheng W, Miao J and Yang J: Radiosensitivity by ING4-IL-24 bicistronic adenovirus-mediated gene cotransfer on human breast cancer cells. Cancer Gene Ther 20: 38-45, 2013.

2. Wu J, Zhang JY, Yin L, Wu JZ, Guo WJ, Wu JF, Chen M, Xia YY, Tang JH, Ma YC, et al: HAP1 gene expression is associated with radiosensitivity in breast cancer cells. Biochem Biophys Res Commun 456: 162-166, 2015.

3. Finnon P, Kabacik S, MacKay A, Raffy C, A'Hern R, Owen R, Badie C, Yarnold $\mathrm{J}$ and Bouffler S: Correlation of in vitro lymphocyte radiosensitivity and gene expression with late normal tissue reactions following curative radiotherapy for breast cancer. Radiother Oncol 105: 329-336, 2012.

4. Ganapathy S, Xiao S, Yang M, Qi M, Choi DE, Ha CS, Little JB and Yuan ZM: A low-dose arsenic-induced p53 protein-mediated metabolic mechanism of radiotherapy protection. J Biol Chem 289: 5340-5347, 2014

5. Agra IM, Filho JG, Martins EP and Kowalski LP: Second salvage surgery for re-recurrent oral cavity and oropharynx carcinoma. Head Neck 32: 997-1002, 2010.

6. Brun SN, Markant SL, Esparza LA, Garcia G, Terry D, Huang JM, Pavlyukov MS, Li XN, Grant GA, Crawford JR, et al: Survivin as a therapeutic target in Sonic hedgehog-driven medulloblastoma. Oncogene 34: 3770-3779, 2015.

7. Markant SL, Esparza LA, Sun J, Barton KL, McCoig LM, Grant GA, Crawford JR, Levy ML, Northcott PA, Shih D, et al: Targeting sonic hedgehog-associated medulloblastoma through inhibition of Aurora and Polo-like kinases. Cancer Res 73 6310-6322, 2013.

8. Xu T, Fan B, Lv C and Xiao D: Slug mediates nasopharyngeal carcinoma radioresistance via downregulation of PUMA in a p53-dependent and -independent manner. Oncol Rep 33: 2631-2638, 2015.
9. Lee SH, Kim DY, Jing F, Kim H, Yun CO, Han DJ and Choi EY: Del-1 overexpression potentiates lung cancer cell proliferation and invasion. Biochem Biophys Res Commun 468: 92-98, 2015.

10. Chiang $\mathrm{C}$ and Ayyanathan $\mathrm{K}$ : Characterization of the E-box binding affinity to snag-zinc finger proteins. Mol Biol (Mosk) 46: 907-914, 2012.

11. Pérez-Losada J, Sánchez-Martín M, Pérez-Caro M, PérezMancera PA and Sánchez-García I: The radioresistance biological function of the SCF/kit signaling pathway is mediated by the zinc-finger transcription factor Slug. Oncogene 22: 4205-4211, 2003.

12. Pérez-Caro M, Bermejo-Rodríguez C, González-Herrero I, Sánchez-Beato M, Piris MA and Sánchez-García I: Transcriptomal profiling of the cellular response to DNA damage mediated by Slug (Snai2). Br J Cancer 98: 480-488, 2008.

13. Yu J, Zhang L, Hwang PM, Kinzler KW and Vogelstein B: PUMA induces the rapid apoptosis of colorectal cancer cells. Mol Cell 7: 673-682, 2001.

14. Feng J, Meng C and Xing D: A $\beta$ induces PUMA activation: A new mechanism for $A \beta$-mediated neuronal apoptosis. Neurobiol Aging 36: 789-800, 2015.

15. Zhang K, Zhang B, Lu Y, Sun C, Zhao W, Jiao X, Hu J, Mu P, $\mathrm{Lu} \mathrm{H}$ and Zhou C: Slug inhibition upregulates radiation-induced PUMA activity leading to apoptosis in cholangiocarcinomas. Med Oncol 28 (Suppl 1): S301-S309, 2011.

16. Kuribayashi K, Finnberg N, Jeffers JR, Zambetti GP and El-Deiry WS: The relative contribution of pro-apoptotic p53-target genes in the triggering of apoptosis following DNA damage in vitro and in vivo. Cell Cycle 10: 2380-2389, 2011.

17. Gauger KJ and Schneider SS: Tumour supressor secreted frizzled related protein 1 regulates p53-mediated apoptosis. Cell Biol Int 38: 124-130, 2014

18. Wang R, Wang X, Li B, Lin F, Dong K, Gao P and Zhang HZ: Tumor-specific adenovirus-mediated PUMA gene transfer using the survivin promoter enhances radiosensitivity of breast cancer cells in vitro and in vivo. Breast Cancer Res Treat 117: 45-54, 2009.

19. Yu J, Yue W, Wu B and Zhang L: PUMA sensitizes lung cancer cells to chemotherapeutic agents and irradiation. Clin Cancer Res 12: 2928-2936, 2006.

20. Wu WS, Heinrichs S, Xu D, Garrison SP, Zambetti GP, Adams JM and Look AT: Slug antagonizes p53-mediated apoptosis of hematopoietic progenitors by repressing PUMA. Cell 123: 641-653, 2005.

21. Arienti C, Tesei A, Carloni S, Ulivi P, Romeo A, Ghigi G, Menghi E, Sarnelli A, Parisi E, Silvestrini R, et al: SLUG silencing increases radiosensitivity of melanoma cells in vitro. Cell Oncol (Dordr) 36: 131-139, 2013.

22. Dillon JK, Brown CB, McDonald TM, Ludwig DC, Clark PJ, Leroux BG and Futran ND: How does the close surgical margin impact recurrence and survival when treating oral squamous cell carcinoma? J Oral Maxillofac Surg 73: 1182-1188, 2015.

23. Inhestern J, Oertel K, Stemmann V, Schmalenberg H, Dietz A, Rotter N, Veit J, Görner M, Sudhoff H, Junghanss C, et al: Prognostic role of circulating tumor cells during induction chemotherapy followed by curative surgery combined with postoperative radiotherapy in patients with locally advanced oral and oropharyngeal squamous cell cancer. PLoS One 10: e0132901, 2015.

24. Huang SH and O'Sullivan B: Oral cancer: Current role of radiotherapy and chemotherapy. Med Oral Patol Oral Cir Bucal 18: e233-e240, 2013.

25. Lo WL, Kao SY, Chi LY, Wong YK and Chang RC: Outcomes of oral squamous cell carcinoma in Taiwan after surgical therapy: Factors affecting survival. J Oral Maxillofac Surg 61: 751-758, 2003.

26. Zhang P, Liu H, Xia F, Zhang QW, Zhang YY, Zhao Q, Chao ZH, Jiang ZW and Jiang CC: Epithelial-mesenchymal transition is necessary for acquired resistance to cisplatin and increases the metastatic potential of nasopharyngeal carcinoma cells. Int J Mol Med 33: 151-159, 2014.

27. Kurrey NK, Jalgaonkar SP, Joglekar AV, Ghanate AD, Chaskar PD, Doiphode RY and Bapat SA: Snail and slug mediate radioresistance and chemoresistance by antagonizing p53-mediated apoptosis and acquiring a stem-like phenotype in ovarian cancer cells. Stem Cells 27: 2059-2068, 2009.

28. Kim S, Yao J, Suyama K, Qian X, Qian BZ, Bandyopadhyay S, Loudig O, De Leon-Rodriguez C, Zhou ZN, Segall J, et al: Slug promotes survival during metastasis through suppression of Puma-mediated apoptosis. Cancer Res 74: 3695-3706, 2014. 
29. Yu J and Zhang L: No PUMA, no death: Implications for p53-dependent apoptosis. Cancer Cell 4: 248-249, 2003.

30. Akhter R, Sanphui P and Biswas SC: The essential role of p53-up-regulated modulator of apoptosis (Puma) and its regulation by FoxO3a transcription factor in $\beta$-amyloid-induced neuron death. J Biol Chem 289: 10812-10822, 2014.

31. Nakano K and Vousden KH: PUMA, a novel proapoptotic gene, is induced by p53. Mol Cell 7: 683-694, 2001.

32. Yu J, Wang Z, Kinzler KW, Vogelstein B and Zhang L: PUMA mediates the apoptotic response to p53 in colorectal cancer cells. Proc Natl Acad Sci USA 100: 1931-1936, 2003.
33. Chen L, Willis SN, Wei A, Smith BJ, Fletcher JI, Hinds MG, Colman PM, Day CL, Adams JM and Huang DC: Differential targeting of prosurvival $\mathrm{Bcl}-2$ proteins by their $\mathrm{BH} 3$-only ligands allows complementary apoptotic function. Mol Cell 17: 393-403, 2005.

34. Funamizu N, Lacy CR, Kamada M, Yanaga K and Manome Y: MicroRNA-203 induces apoptosis by upregulating Puma expression in colon and lung cancer cells. Int J Oncol 47: 1981-1988, 2015. 